UDC $622.323: 553.982(55)$

\title{
アラビヤ湾に打ける中立地帯沖合油田の開発
}

一眧和 35 年 10 月 25 日特別講演——

アラビア石油株式会社 舟・越竜

要旨 : 一アラビヤ石油株式会社によつて実施されているアラビヤ湾の中立地帯沖合油田の開 発に関するもので，その利権の獲得，探鉱，試掘，掘整の経過扣よび現状をやや詳細に述べ， また同地区産原油の性状, 将来の産出量, 埋藏量, 原油搬出の計画, 施設をも併せて述べたも のである。

中立地帯というのは，クウェイス国とサウジアラビ ア国との中間に存在する地域であつて，クウェイト国 の領土であると共にサウジアラビアの領地でもあると いう，両国の権益が半分宛ある地帯である。これをニ シートラルゾーンといつている。このニニートラルゾ ーンの沖合もまた, アラビア湾の中心線までは, 陸地 同様に両国の権益が及ぶことになつている。

アラビヤ石油ではこの海域の鉱区権を取つて，只今 油井を掘削している。掘削地点は海岸から東方約 45 $\mathrm{km}$ の海上である。

第 1 号井は本年 1 月末に成功して，その後引き続き 2 号，3号，4号，5号と掘り進み， 5 号井は去る10 月16日に完成した。これらの坑井は，いずれも日産 $1,000 \mathrm{kl}$ 以上の生産能力を有することが試験の結果に より判明している。第 6 号井は本月末には完成する筈 である。

ここではこの油田の開発について, 今までの経過お よび現況について少し詳しく述べ，なお将来の生産，

船出の構想，計画などを述べてみたいと思う。

すでに御承知かとも思うが; 始めからの経緯を簡単 に述べる。

まず利権の獲得であるが，山下社長が中東地方の石 油の開発に関心を持ち，岡崎元外務大臣などと共に一 ケ年半にわたり現地に滞在して，獲得したものであ る。ちろんこの地方の日本の外務省の方々の御応援 もあつたよらであるが，昭和32年の12月にサウジ政府 と調印され，その翌年の7月にはクウェイト政府とも 調印されている。非常に競争者があつて, 英米の有力 な大会社と競り合つたのであるが遂に両国から権利の 獲得に成功したのである。

利権地域はニュートラルゾーンの沖合であつて, 南 北約 $70 \mathrm{~km}$, 東西約 $100 \mathrm{~km}$ といら広大な海域である。
そこで直ちに探鈗にかかつたのであるが，これを米国 の有名な地震探鉱会社であるジオフィヂカル.サー心 インターナショナル (GSI)という会社に請負わせて実 施した。この方法は, 海中でダイナマイトを爆発させ て, その震動波を地下に伝え, 地層から反射してくる 震波を海上に浮べた地震計がキャッチしてその速度を 記録して, 地下の構造を知る方法である。この方法は 石油の探鉱に世界中何処でも実行しているものであつ て，日本でも実施している最新式の方法である。探鉣 技術も随分進歩してきたけれども，まだ石油そのもの をズバリと探し当てる方法は，世界中何処にもできて いない。石油が胚胎している可能性のある地下構造を 知るだけである。構造の中に石油があるか, 水がある か, ガスがあるか, 温泉があるかは, 掘つてみなけれ ば解らないのである。

この探鉱を33年の 8 月から11月の半ばにかけて実施 した。陸上と異り海上では船を使用するので非常に速 くできる訳である。

その結果は鉱区内に立派な構造が数ケ所あることが 判明した。石油の本場において立派な構造があること がわかれば，甚だ有望であるので，直ちに試掘をする ことになつたのである。

同年の11月末には米国のインターナショナル・ドリ リング会社へ掘鈠を請負わせることにした。このよう な外地において, 海洋掘䉧を実施することはまだ日本 の会社では手に負えない訳である。

そこで今度は掘鋫のことになるが, 海洋掘鏊には種 々な方法がある。船の中から掘る方法, 船の舷側で掘 る方法など船から掘る方法もあるが，船は海面に浮ん でいるもの故, 波浪に摇られるので, 地中媣く井戸を 掘ることは，そう簡単にはできないのである。つぎに 人工島を作つて掘ることであるが，アラビヤ湾の現地 
においては水深が $30 \mathrm{~m}$ 以上もあるので，この処に島 を作ることは容易ではない。

目下米国において盛んに使用されている方式はモビ ール・プラットフォーム方式である。これは一種のバ ージに数本の脚を取り付けたものであつて, 航行中は 脚を上げて曳行される。目的地点に着くと脚を下げて 海底に着ける。なおモーターを名すと，脚はこれ以上 海底に下らないから，こんどはバージ自身が空中へ上 つてゆくのである。大きな波浪の場合にもバージの本 体に波が届かない程度にバージを上げて作業をする訳 である。

この方法は 2 種類あつて，バージが 3 角形をしてい て脚が 3 本のものと，バージが 4 角形をしていて脚が 4 本乃至 8 本のものとある。前者をルトーノ一式, 後 者をデロング式といつている。

日本の石油資源会社では前者を作つて，目下秋田市 油で掘つている。アラビヤ石油においても, 同一方式 を採用して，第 1 号井以下第 5 号井まで掘つた。今 6 本目を掘鐜中である。

つぎに只今はなお別な方式により掘つている。これは フィッキスド・プラットフォーム. ウイズテンダー方 式である。これは恰も「脚立」を海中に立てたような ものであつて，4本脚の脚立をおき，その脚の中に鉄 管の杭を打ち，海底にしつかりと取付けるのである。 この上に櫓，掘鏫機を取り付けて掘る訳である。掘龆鉒 に必要なポンプや発電設備や宿舎などは, 接近して停 泊しているテンダーボートに設置する。この方式によ り只今 SEA CTA 社に掘錐させている。

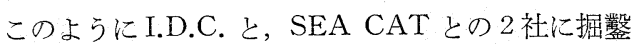
させている。

掘蔹請負業者は予定深度まで故障なく坑井を掘るこ とが責任であつて，油が出ようが出まいが損得はない。 油層を見付けることや，油の出るように坑井を仕上げ る計画は凡てアラビヤ石油の方で決定する。地層の状 態をみて水止め深度, 掘止深度などの決定, 仕上げ方 法の決定, 油量試験の方法などは当方で定めて, これ 艺請負者化指示する。

1 坑の完成までの日数は, 海上作業であるので, 従 来は2 ケ月を要していたが, 近来は漸次短縮されつつ ある。1式で 1 ケ年間に 8 坑は掘鍫できるものと思 う。 2 式では年間16坑位は可能と考えている。

1 号井は前述のと㧍りモビールプラットフォームに より昨年の 7 月より掘り始めたが，深度 1,479 呎まで 掘つた時に, 突然に強烈なガスが猛噴して, 火災を起 した。そのために欍, 掘削機などを焼損した。火災は
米国から有名な，油田の火消しを飛行機で呼び，10日 目に消しとめることができたが，燒損機械器具を米国 から輸送して取替えたために再開は11月末となつた。 その後は順調に掘り進むことができて翌35年の 1 月末 に成功した。坑井地質は大体上部はドロマイトとアン ハイドライトとの互層をなしている。下部になるに従 つてライムストーンが多くなる。上部は第 3 紀層であ るが，下は白亜紀となる。それから頁岩が出てくる。 砂岩も出て, 頁岩と砂岩との互層となる。

砂岩に油が含まれている。オイルサンドとなつてい る訳である。下部へくるとほとんどオイルサンドの層 となる。この層が合計約 600 吹も連続する。これがい わゆるブルガン層である。ブルガン油田や, サファニ ヤ油田の主体層をなしているものである。電気検層を 実施して，その内でも最も良好と思われるところをガ ンパーフォレートして, 鉄管に穿孔して油を出してい る。それが約 300 呎位の長さである。すなわち 600 炚 の油層の内 300 呎の所から出油せしめているので㐫 万。

このようにして，坑内にチニービングを入れて自噴 せしめている。坑口にクリスマスツリーを取り付け て，いつでもバルブを開けば自噴せしめることができ るようにして一応密閉してある。

2 号井は 1 号井の西方約 $4 \mathrm{~km}$ の地点に掘つたが地 質は 1 号井と全く同じである。産油能力も同じであっ た。 2 号井は 1 号井の西方 $4 \mathrm{~km}$ も離孔ているので油 層が約 200 呎位下っているものと想像していたが，実 際には 50 呎位しか下っていなかつた。これは構造の 幅が広いことを意味するのであつて, さらに $4 \mathrm{~km}$ 位 西方の地点にも掘れると考えている。

3 号井は 1 号井の東方約 $1.6 \mathrm{~km}$ の地点へ掘つた。 これも 1 号井 2 号井と同じ地質である。生産量もまた 同様である。従つて，これまたなお東方へ油井を作る ことができると思う。

4 号井は 1 号井より西南方約 $1.6 \mathrm{~km}$ の地点である。 これも前記各坑井と地質, 油量共に大差はない。ただ 乙前記の第 3 号井より油量はやや多いようである。ま た油層も本井が一番隆起している。背斜軸は今までの データーでは本井附近を南北に走つているものと想像 される。これは今後多数の坑井を掘ることによつて解 決される筈である。

5 号井は最近の成功井であるが; これは 1 号井の北 方約 $1.6 \mathrm{~km}$ の地点にある。去る 10 月 16 日に完成して いるが, 油量, 地質共前記各坑井と同様である。要す るに非常に大きな構造の中に掘つているのでするか 
第 1 表 カフジ 1 号井およびサフアニヤ油田の原油性状

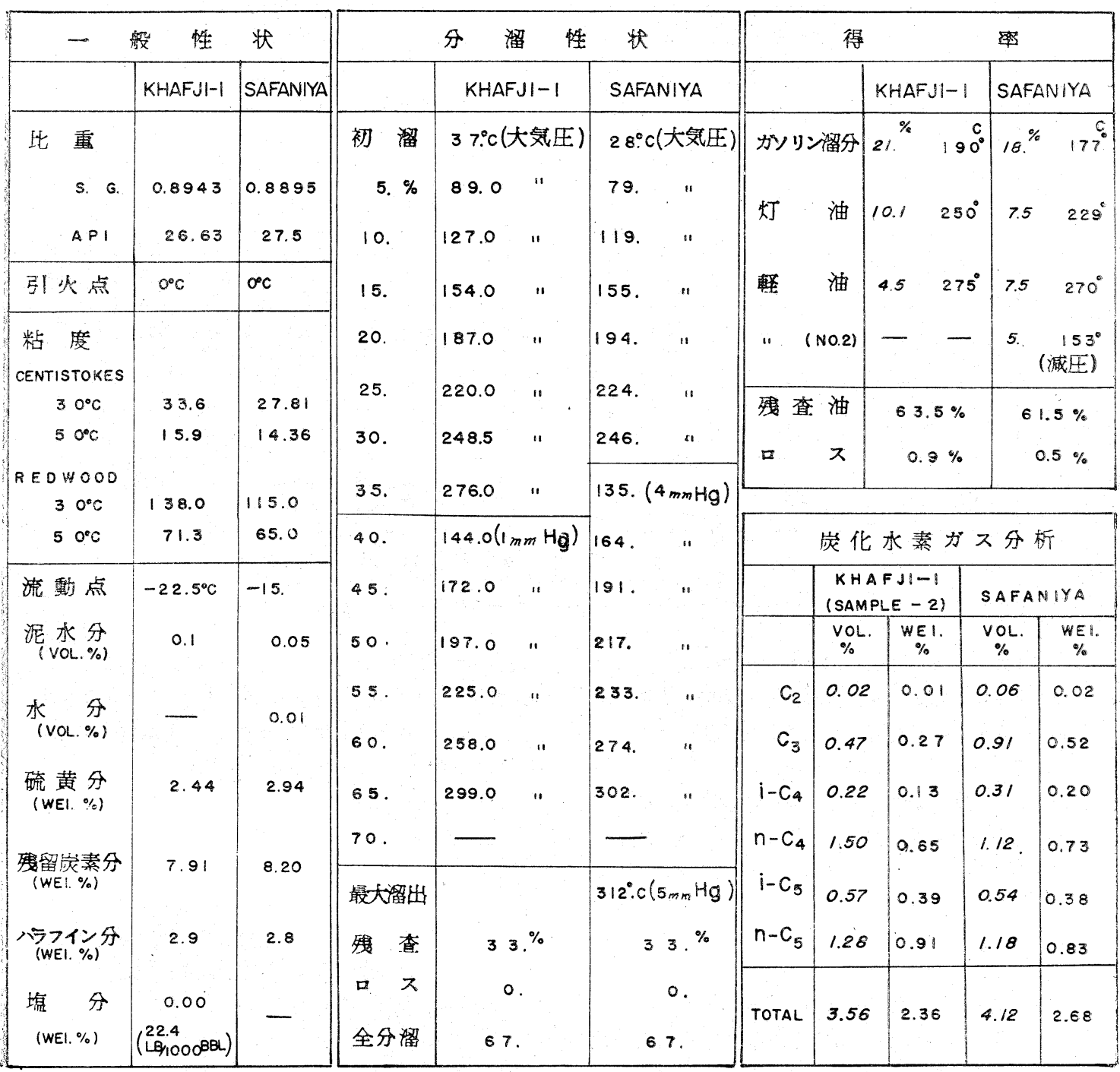

ら，同じとなる訳である。坑井間隔を $1.6 \mathrm{~km}$ という ように甚だ広くしていてなおかつ，各井共同一である ということで如何にその構造が大きくあるかというこ とが御理解できるかと思う。日本においては，坑井間 隔を $200 \mathrm{~m}$ にしても，各井それぞれ地質が異り，かつ 生産量に多大の相違がある。無出油井もできるのであ る。これに反して当社のものは世界の大油田たる性格 が表われている。只今開発している構造だけでも多数 の油井が掘れる広さを持つていると考㝋ている。

原油の性質は，第 1 表のと扝りであつて，サファニ ヤ原油と同様である。ややそれより良質となるかと思 う。ガソリン分よりも重油分が多く, 日本でいら重質
油である。ボーメ $26.6^{\circ}$ API である。

油量は各井共成功当初において試験をしており，そ の結果は公表している。日産 $1,000 \mathrm{kl}$ 以上の能力を持 つている。しかし実際に搬出すると，採取できない日 もある。ことに海上にタンカーを並べて貯油するので あるから，安全のために搬出油量としては，内輪に計 画して 1 日 1 坑井当り $800 \mathrm{kl}$ を出すものとして計算し た。従つて採収井数も 40 坑位で年産 1,000 万 $\mathrm{kl}$ を実 際に生産するものと考えている。これについては実例 が附近の油田にあるので，この点について少し述べて みたいと思う。数字は本年 8 月 15 日発行のワールド才 イル誌の数字を使用する。 
第 2 表 カフジ油田周辺の各油田における産油量

\begin{tabular}{|c|c|c|c|c|c|c|c|}
\hline 油 & $\begin{array}{l}\text { 産 油井数 } \\
\text { (END of 1959) }\end{array}$ & 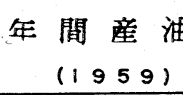 & & \multicolumn{2}{|c|}{$\begin{array}{c}\text { 平均日座最 } \\
(1959)\end{array}$} & \multicolumn{2}{|c|}{ 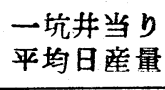 } \\
\hline BURGAN & 319 & $\begin{array}{l}504,855,244 \\
(80,271,984\end{array}$ & $\begin{array}{l}B 8 L \\
K L)\end{array}$ & $\begin{array}{r}1,383,165 \\
1219,923\end{array}$ & $\begin{array}{l}B B L \\
K L)\end{array}$ & $\begin{array}{r}4,336 \\
1689\end{array}$ & $\begin{array}{l}\text { BBL } \\
K(L)\end{array}$ \\
\hline WAFRA & 178 & $\begin{array}{l}42,438,490 \\
(6,747,720\end{array}$ & $\begin{array}{l}8 B L \\
K L)\end{array}$ & $\begin{array}{r}116,270 \\
(18,487\end{array}$ & $\begin{array}{l}B B L \\
K L)\end{array}$ & $\begin{array}{r}653 \\
1104\end{array}$ & $\begin{array}{l}B B L \\
K L)\end{array}$ \\
\hline GHAWAR & 91 & $\begin{array}{l}256,173,790 \\
(40,731,633\end{array}$ & $\begin{array}{l}8 B L \\
K L)\end{array}$ & $\begin{array}{r}701,846 \\
(111,594\end{array}$ & $\begin{array}{l}B B L \\
K L)\end{array}$ & $\begin{array}{r}7,713 \\
(1,226\end{array}$ & $\begin{array}{l}B B L \\
K L)\end{array}$ \\
\hline$A B Q U A 1 O$ & 56 & $\begin{array}{r}97,570,340 \\
(15,513,684\end{array}$ & $\begin{array}{l}B 8 L \\
K L)\end{array}$ & $\begin{array}{r}267,316 \\
(42.503\end{array}$ & $\begin{array}{l}B B L \\
K L)\end{array}$ & $\begin{array}{r}4,774 \\
1759\end{array}$ & $\begin{array}{l}B B L \\
K L)\end{array}$ \\
\hline SAFANIYA & 21 & $\begin{array}{l}27,804,605 \\
(4,420,932\end{array}$ & $\begin{array}{l}\text { BBL } \\
K L)\end{array}$ & $\begin{array}{r}76,177 \\
112,112\end{array}$ & $\begin{array}{l}\text { B8L } \\
K L)\end{array}$ & $\begin{array}{r}3,628 \\
1577\end{array}$ & $\begin{array}{l}B B L \\
K L)\end{array}$ \\
\hline DAMMAM & 25 & $\begin{array}{l}12,430,440 \\
11,976,440\end{array}$ & $\begin{array}{l}B B L \\
K L)\end{array}$ & $\begin{array}{r}34,056 \\
(5,415\end{array}$ & $\begin{array}{l}B B L \\
K L)\end{array}$ & $\begin{array}{r}1,362 \\
1217\end{array}$ & $\begin{array}{l}B B L \\
K L)\end{array}$ \\
\hline QATIF & 8 & $\begin{array}{r}5,841,415 \\
(928,785\end{array}$ & $\begin{array}{l}\text { BBL } \\
K L)\end{array}$ & $\begin{array}{r}16,004 \\
12,545\end{array}$ & $\begin{array}{l}\text { BBL } \\
K L)\end{array}$ & $\begin{array}{r}2,001 \\
(318\end{array}$ & $\begin{array}{l}\text { BBL } \\
\text { KL) }\end{array}$ \\
\hline
\end{tabular}

まずブルガン油田であるが，これはクウェイト国の クウニイト市の南方にある世界最大の油田である。ク ウニイト石油会社が経営している。この油田は1938年 加開発されて, 現在採収井 319 坑ある。昨年の生産 量注間 8,000 万 $\mathrm{kl}$ であつた。年間 8,000 万 $\mathrm{kl}$ の生産 量注，世界で第 4 位となる。米国，ベネゼラ，ソ連に つぐ産油国であつてクウェイトは, 一つの油田だけで 世界の第 4 位の産油国となつているということは誠に 驚異である。しかもブルガン層だけである。そのブル ガン層が当社の採油層である。

クウェイト国へはこのブルガン油田の利権料が毎年 数億ドル入るといわれている。人口僅かに 25 万人であ る。従つて街法非常海繁華である。元来が小さな魚港 であつたクウェイト市が今は立派な道路を持ち, ブロ ック建築の堂々たる商店や官庁が並んでおり, 最新型 の自動車が複奏している。回教国であるので酒はない が，しかしレストランはある。バーやキャバレーのご ときものはない。しかし乞食も泥棒もスリもいないし 街の女もいない。呚嘩もないので全くの聖なる都であ る。砂漠の中に人類の理想の聖地ができているのであ る。しかも日本人に対しては非常に近親感を持つてい る。また尊敬しているようである。戦後の日本人とし ては意外な処に意外な親友を発見したといら感を強く するものである。

クウェイトにはこの他にラウダテンという油田があ
る。これはクウュイト市の北方約 $100 \mathrm{~km}$ 位の処にあ つて，イラクの国境に近いのであるが，1955年に発見 している。只今採油井数が38玾であつて本年の 4 月か ら採取している。ワールドオイルの統計は1959年のも のであるので，これには出ていない。本年は相当の生 産をするものと思う。

つぎに中立地帯にワフラ油田がある。この油田は19 53年から開発されたが採油井数 178 坑であつて昨年は 約 700 万 $\mathrm{kl}$ を産出している。特徴はエオシンの油を産 出する油井が 30 坑ある。この層は浅層であつて, 当 社の鉣区でも 1,500 呎の所に同じ層がある。第 1 号井 において災を起した層である。この油田はアミノイ ルといら会社とゲテイといら二つの会社で経営してい る。アミノイルはクウェイト国から権利を取りゲテイ はサウジアラビヤから権利を得ているのであつて, 生 産量を折半している。すなわち 350 万 $\mathrm{kl}$ 宛両社乞れぞ れ生産しているといら訳である。当社は両国から権利 を得ているのでこのような不利はないのである。

つぎはサファニア油田であるが，これは当社の油田 から南方約 $30 \mathrm{~km}$ の地域にあるサウジアラビヤの油田 である。経営者はアラムコである。サウジアラビヤの 国の権利はアラムコで取つている。アラムコはアメリ カン・アラビアン・カンパニーの略である。坑井は33 坑あるが，昨年は21坑より採取して約 440 万 $\mathrm{kl}$ を採取 している。しかしこの油田は年産 1,000 万 $\mathrm{k} 1$ を生産す 
る能力があるといわれている。只今はフルに活動して いるとのことであるので，本年は 1,000 万 kl を生産 するものと思われる。

サファニア油田は世界最大の海洋油田である。この油 田の南方約 30 哩の海上にマニファ油田がある。これ は1957年に発見されて油井が 5 坑あるが，まだ開発さ れていない。これも完成の上は相当な油田となるもの と思われる。

サウジアラビヤには, この他に多数の油田を持つて いる。ガワール・アブカイク・ダンマム・カテフなど であつて，これら油田の生産量は合計で 6,400 万kl と なる。井数は 201 玾である。

その他アラビヤ湾の西岸にはバハレン・ヅカン油田 などがある。またイラン・イラクにも多数の油田があ る。

このようにアラビヤ湾を囲んで, 多くの油田があつ て，、ずれも世界の第一級の油田である。昨年の統計 によると，世界に扔汀る大産油国の順位は，1位北米 合衆国，2位心゙ネゼラ， 3 位ソ連，4 位クウェイト 5 位サウジアラビヤ，6位イラン，7位イラクとなつ ている。生産量, 井数などは第 3 表のとおりである。 1 玾当りの生産量の最も多いのはイランであつて 1,500kl/日 で次がイラク，サウジアラビヤ，クウェイ 卜の順で, クウェイトは 1 坑当り $700 \mathrm{kl} /$ 日 近く出し ている。世界最大の生産国である北米合衆国は, 井数 が 57 万坑すあるので, 1 坑当りの日産は僅かに $2 \mathrm{kl}$ で ある。その他べネセラは $42 \mathrm{kl}$ ，ソ連は $11 \mathrm{kl}$ である。 従つて中東地方は今後坑井数も増加することによつて 世界の最大産油国の順位に番狂わせを来すものと思 亏。

しからば果してどの位の埋蔵量を有するかというと 第 3 表がこれを示している。北米合衆国が 50 億 $\mathrm{kl}$ に 対して,クウェイト95億 $\mathrm{kl}$, サウジアラビヤが76億 $\mathrm{kl}$ で埋蔵量の点ではクウェイトが世界第 1 位である。第 2 位サウジアラビヤ，第 3 位北米合衆国，第 4 位がソ 連とイラク，第 5 位イラン，第 6 位ベネゼラである。

このように中東地方, ことにアラビヤ湾とその周辺 地域は, 将来性のある産油地である。

従来はこれらの開発はすべて英米の資本であつて, 経営もまた英米人が独占していた。この檜舞台へ日本 人が進出したので, 英米人も現地人も警いている訳で ある。従つて私共は日本の面目にかけても成功しなけ ればならないと，深く責任を感じている次第である。

つぎに沖合油田は生産施設が重要である。 坑井間隔は前述のとおり 1 哩としたが，これらの坑
井約10坑を以つて1単位として, その油井群の中心附 近にフロー・ステーションを建設する。この上にはセ パレーターを置いて各油井からここまで，フロー・ラ インを敷設する。これは 6〜8in の海底管である。坑 井からの自噴原油は, この海底管によりフロー・ステ ーション上のセパレーターに入る。自噴圧力は 4001 bs/in 位であるが，このところで $200 \mathrm{lbs} / \mathrm{in}$ まで落 す。従つてその間に溶解ガスは 1 部気体となるので, セパレーターで分離したガスはフレヤー・ラインへと おして, 約 1,000 呎離れて然焼する。もちろんフレヤ 一・ラインも海底に敷設する。フローステーションは $1 つ の$ 構造に対して数個できる筈であるから, 適当な ところへギャザリング・ステーションを建設して, 各 フロー・ステーションからここまでギャザリング・ラ インを引き, フロー・ステーション上にはポンプでギ ヤザリングラインをと抗して送る。ギャザリング・ス テーションには大型ポンプを設置して, ここから陸上 へ送るのであるが，そのために陸上までトランスミッ ションラインを引き， $26 \mathrm{in}$ パイプを $45 \mathrm{~km}$ 敷設する構 想である。ギャザリング・ラインは 12 in 計画してい る。

かくして各油井の原油はフロー・ステーションに集 まり，ポンプでギャザリングステーションへ送られ， ここで再度ポンプにより陸上へ送られるのである。

陸上には大型タンク数基を建設して原油はこれに貯 蔵される。海上には約 $5 \mathrm{~km}$ 沖合にオーシャン・タン カーが横付けできるよらなプラットフォームを構築す る。タンクヤードからポンプステーションをとおつて ここまでローデング・ラインを海底に敷設する（附図 参照)。

これら海上および陸上のポンプの開閉および各記録 はすべて，陸上の操作室で遠方操作をする。なおまた すべての動力は陸上の発電所から海上の各設備の電動, 機には海底ケーブルによつて送電する構想である。し かし乍らこれらの諸設備は, まだ構想の域を脱しない ので目下研究中である。実施するとしても完成までに は 1 ケ年半乃至 2 方年を要する。

そこで応急搬出方法を計画している。この方法は原 油を陸上に貯油する代りに，タンクを海上に置く方法 である。海上タンクには老朽した戦標型タンカー（古 タンカー） 5 隻を使用することにした。すなわちフロ ー・ステーションから 5 隻のステーションタンカーヘ 海底管を引いて，ここに貯油する。それからまたオ一 シャン・タンカーの停泊地までパイプを引いて，ステ ーション・タンカーのポンプでオーシャン・タンカー 
第 3 表 原油確定埋蔵量と産油量および産油井数

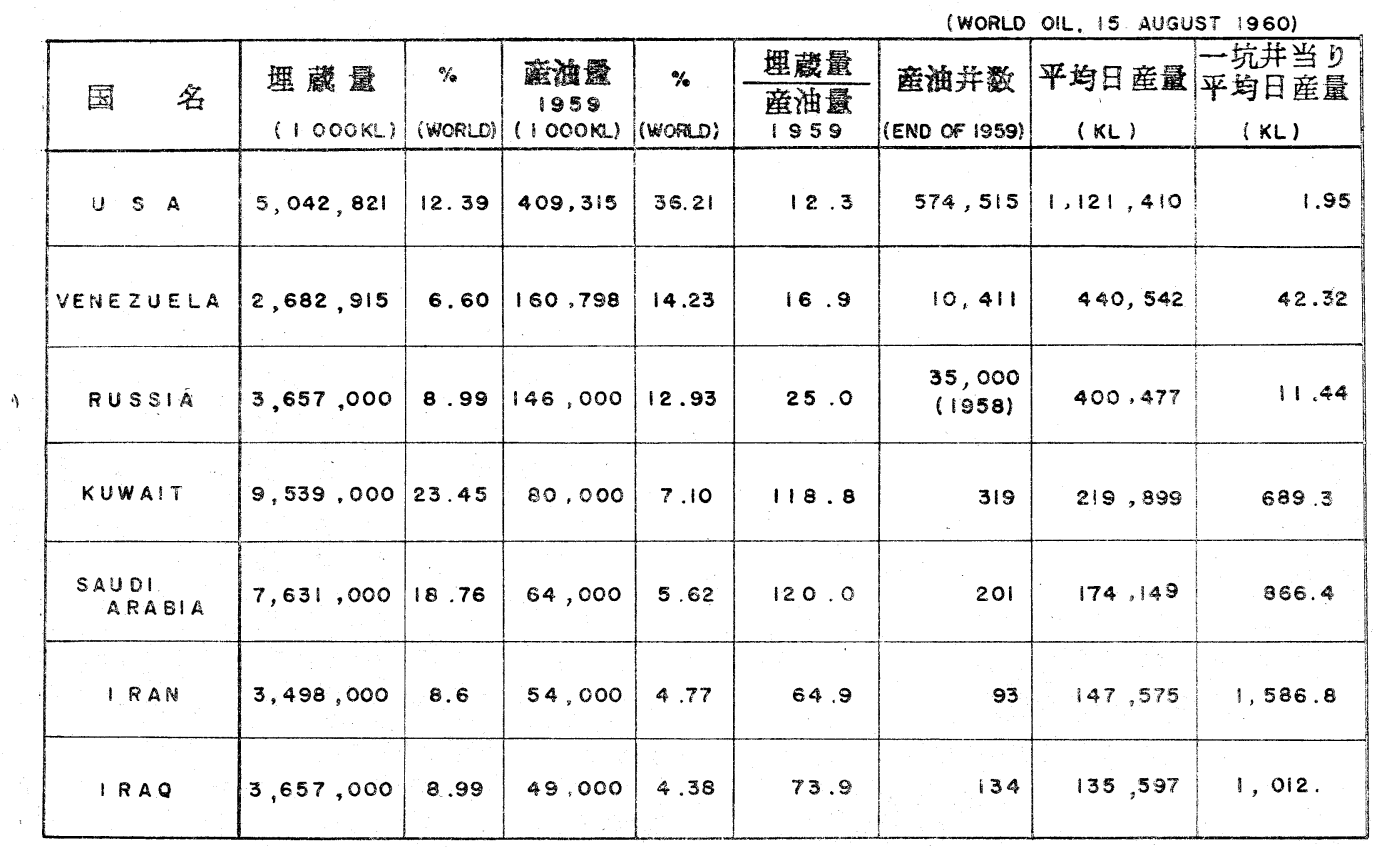

へ送油するのである (附図参照)。只今はこの設備の 建設を急いでいるので，本年末までに浣成するすの と期待している。すでにステーション・タンカー 2 隻 は本月の 20 日に神戸港を出発している。他の 3 隻も引 き続き日本を出発することになつている。

このような訳であるので，本年末または来年の 1 月早 々には油送船がアラビヤ湾を出発し，今月末には日本 へ到達することが可能と考えている。

つぎに海上の油田であるので岸に基地が必要であ る。資材の集積や, 構築物の組み立て, タンクヤー ド, 発電所, 造水工場などのため広大な基地がなけれ 䟽らない。始めはコール・ムハッタという所を借用 していた。クウェイト市から約 $105 \mathrm{~km}$ 南方にある入 江である。ここはアミノイル会社の荷掦場であるが, 港が狭いのでな扔南へ $31 \mathrm{~km}$ 下つたカフジといら所へ 新基地を建設中である。ここも入江であうて，油田の 业る所まで約 $45 \mathrm{~km}$ であつて, 最短巨離の地点であ る。人家む何もない荒凉たる砂漠の入江である。ここ に埠頭を作り港や水路を浚渫して良港を作つた。只今

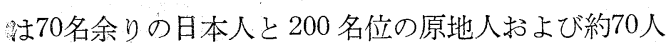
の米人その他各国人が，アラビヤ石油のために諸作業 连行つている。

永久設備が完成する頃には日本人も数百人となり,
その他の国の人も 1,000 人を越えるのではないかと思 う。いずれにしても，アラビヤの砂漠の一角に日本部 落が出現することとなる。

かくして，日本人がアラビヤ湾岸で生活することによ り，日本の貿易の振興にも役立つものと思われる。幸 いにアラビヤ人は非常に親日的である。戦争で大分日 本は世界の信用を落したのではないかと思われるが， アラビヤ人は日本を信用し, かつ親密感を持つてい る。この点は事業をするのに好都合である。

なお私共の仕事は大部分を米国の業者传青負わ证て いるが，業種の性質上，殊に海上油田であるので，ヨ 本の業者に経験がなく，目下の処残念乍ら米人に請負 わせているのである。しかしこれらと契約しかつ作業 の監督は日本技師が当つている。

将来は請負業者も遂次日本人に移行したいものと念 願している。

御承知のとおり日本の石油消費量は年々莫大な増加 を来しているので，海外に利権を得てこ礼に役立てる ことは重要なことと考えている。なおこの事業によつ て, 中東地方諸国と友好関係を結び，日本の貿易振興 に幾分なりとも寄与できるならば喜ばしいことと思 う。何卒皆様の御支援御鞭韃をお願いする次第であ る。 


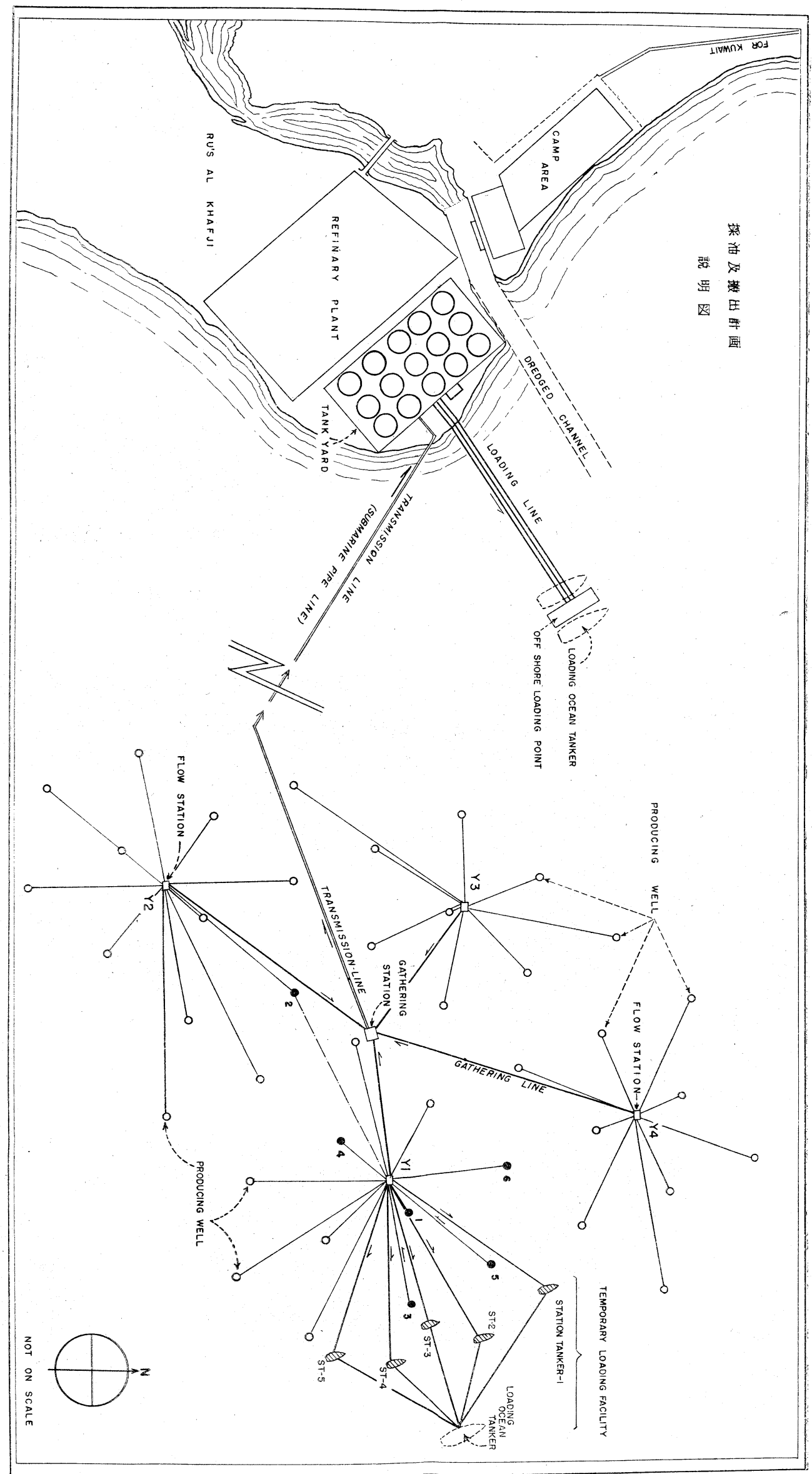




\section{Exploitation of the Oil Field off the Coast of the Neutral Zone in Arabian Bay}

by Lyu Funakoshi

(Arabian Oil Co.)

SYNOPSIS:-This paper relates the development of the exploitation of the oil fields off the coast of the neutral zone in Arabian Bay by Arabian Oil Co. The progress and present state of the mining rights, the exploration, the trial digging and oil mining are described in a little detail. The nature, reserve and expected produce of the crude oil in these fields, the sheme of mining equipment, facilities and carrying out of the oil are also described.

\section{オランダ国営炭鉱の業樍好調}

内外の炭界不況にもかかわらず，多角経営と設備の近代化（出炭の $46.4 \%$ が機械化）による生産コストの 引下などにより，59 年の同鉱業績は好調であつた（表 1-2）。

\begin{tabular}{|c|c|c|c|c|}
\hline \multicolumn{5}{|c|}{ 第 1 表 オランダ国営炭鉱の生産高 } \\
\hline & 1956年 & 1957年 & 1958年 & 1959年 \\
\hline 石炭……………… $1,000 \mathrm{t}$ & 7,495 & 7,232 & 7,551 & 7,506 \\
\hline 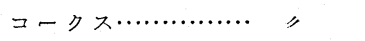 & 2,934 & 2,955 & 2,866 & 2,835 \\
\hline 肥料 $\cdots \ldots \ldots \ldots \ldots \ldots \ldots \ldots \ldots$, & 753 & 902 & 919 & 942 \\
\hline 化成品…………... & 7.7 & 10.3 & 13.8 & 21.3 \\
\hline コークス炉ガス，100万 $\mathrm{m}^{3}$ & 1,232 & 1,252 & 1,209 & 1,214 \\
\hline 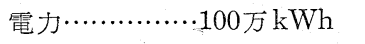 & 987 & 988 & 1,066 & 1,280 \\
\hline \multicolumn{5}{|c|}{ 第 2 表 オランダ国営炭鉱の営業成績 (100万グルデン) } \\
\hline & 1956年 & 1957年 & 1958年 & 1959年 \\
\hline 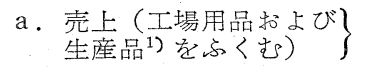 & 945 & 1,036 & 1,087 & $1,058^{1)}$ \\
\hline 前年比 $\cdots \cdots \cdots \cdots \cdots \cdots \cdots$ & $+7 \%$ & $+10 \%$ & $+5 \%$ & $-3 \%$ \\
\hline b. 同（上記品目のぞく） & 580 & 630 & 657 & 652 \\
\hline 前年比 …………….... & $+9 \%$ & $+9 \%$ & $+4 \%$ & $-1 \%$ \\
\hline 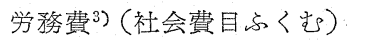 & 304 & 339 & 370 & 365 \\
\hline 利益（罆債 ${ }^{4}$ )引去前）….. & 59.3 & 58.6 & 55.9 & 68.5 \\
\hline a に吱し…….................. & $6.3 \%$ & $5.7 \%$ & $5.1 \%$ & $6.5 \%$ \\
\hline b に対し $\ldots \ldots \ldots \ldots \ldots \ldots \ldots \ldots$ & $10.2 \%$ & $9.3 \%$ & $8.5 \%$ & $10.5 \%$ \\
\hline 積立金と引(立金 $\left.{ }^{5}\right) .$. & 10.6 & 12.8 & 16.4 & 26.7 \\
\hline 配当 $\cdots \cdots \cdots \cdots \cdots \cdots \cdots$ & $11 \%$ & $11 \%$ & $10 \%$ & $13 \%$ \\
\hline$\cdots \cdot$ & 80 & 82 & 78 & 82 \\
\hline 償却…... & 56 & 60 & 62 & 63 \\
\hline
\end{tabular}

1) innerbetriebliche Lieferungen u. Leistungen 2) 1 グ

ルデン 100 円とすれば1,058億円 3) 年度末従羘員数は42,400

人で, '58より 2,100 人少い4) Belastungen 5) Rueckst-

ellurgen

Maurits にコークス炉 2 (石炭各1,000t/日)ができ，これで, 15,000万グルデンを投に゙，10年以上にわたつ た近代化計画は完成し,能力の70\%が更新された。この年度にポリエチレンの生産が開始され, “Stamylan*” の名で合同プラスチック販売会社 (Verenigd Plastic Vorkoopkantoor N. V., Zeist) から売出された。 なお，ダウケミカルと共同でロッテルダムにフエノール工場を新設，製品の1部はナイロン用として Algemene Kunstsijde Unie に供給の予定である。(Glückauf, 96, (16) 1024 '60; Erdöl u. Kohle, 13, (9) 716 , (10) 812 ’60) *馬場・川村活加, 石炭化学工業 (1960, 産業図書, p. 466 参照（ヒロタ） 